Н. В. Курділь ${ }^{1}$, Б.С. Шейман', О.В. Іващенко ${ }^{2}$, А. В. Рогов ${ }^{3}$, Т.Ю. Сафір 'ДП «Науковий центр превентивної токсикології, харчової та хімічної безпеки імені академіка Л.І. Медведя Міністерства охорони здоров'я України", Київ

${ }^{2}$ Національна медична академія післядипломної освіти імені П.Л. Шупика, Київ

${ }^{3}$ Центр екстреної медичної допомоги та медицини катастроф КМДА, Київ ${ }^{4}$ Міжрегіональна академія управління персоналом, Київ

\title{
Цивільно-правові аспекти дистанційного консультування у разі небезпечного хімічного інциденту: «закон доброго самаритянина»
}

В Україні, за відсутності спеціалізованих токсикологічних центрів, консультативна допомога уразі хімічних інцидентів надається спеціалістами оперативно-диспетчерської служби центрів екстреної медичної допомоги та медицини катастроф. Сьогодні в окремих країнах світу оперативно-диспетчерська служба використовує положення «закону доброго самаритянина». Мета дослідження - аналіз досвіду окремих країн у питаннях реєстрації телефонного повідомлення про небезпечний хімічний інцидент на основі «закону доброго самаритянина». Методи дослідження: контент-аналіз, порівняльний аналіз. Результати. На початку 2020 р. мережа консультативних токсикологічних центрів у світі була представлена 313 установами у >150 країнах світу. За останні 20 років у роботі центрів підвищується попит утелефонних консультаціях, інтернет-ресурсах, зокрема соціальних мережах, що містять інформацію про потенційні отрути (наркотики, алкоголь, ліки, пестициди, агрохімікати, вироби побутовоїхімії тощо). Важливим аспектом у комунікації між оператором і абонентом є цивільно-правова відповідальність за повідомлення про інцидент, що пов'язаний із дією небезпечних хімічних речовин (наркотичних, токсичних, вибухонебезпечних тощо), яка передбачена «законом доброго самаритянина». У статті продемонстровано дані про позитивні результати імплементації положень закону до роботи екстрених служб США та інших країн. Висновки. Юридичне закріплення принципів надання консультативної медичної допомоги за «законом доброго самаритянина» дозволяє в багатьох країнах світу щороку зберегти від передчасної смерті сотні життів, тому імплементація цих положень у законодавство України у сфері охорони здоров'я $є$ актуальним питанням для профільного міністерства та професійних медичних асоціацій.

Ключові слова: гострі отруєння, екстрена медична допомога, «закон доброго самаритянина».

\section{Вступ}

У рамках науково-дослідних робіт, здійснених у ДП «Науковий центр превентивної токсикології, харчової та хімічної безпеки імені академіка Л.І. Медведя Міністерства охорони здоров'я України» в період 1995-2015 рр., встановлено, що гострі отруєння хімічної етіології переважають серед населення молодого і працездатного віку та мають стійку тенденцію до поширення, що підтвердило важливий соціальний, медичний, економічний і безпековий статус цієї проблеми (Трахтенберг И.М., 2010; Шейман Б.С. и соавт., 2014).

Сьогодні є очевидним, що формування чіткої системи управління таким видом спеціалізованої медичної допомоги, як токсикологічна допомога, зокрема здійснення державного соціально-гігієнічного моніторингу гострого токсичного впливу на здоров'я населення, $є$ важливою функцією системи громадського здоров'я та невід'ємним елементом системи хімічної безпеки держави (Проданчук М.Г. та співавт., 2019).

Дослідження виконано в рамках науково-дослідної роботи на тему «Наукове обґрунтування безпеки для здоров'я людини пестицидів та агрохімікатів, нових технологій, речовин, матеріалів, виробів, об'єктів довкілля, харчових продуктів та продовольчої сировини; розробка відповідних медичних критеріїв і показників (санітарних та епідеміологічних); санітарнохімічна, токсиколого-гігієнічна оцінка, регламентація, нормування».

Мета дослідження - аналіз діяльності консультативних токсикологічних центрів (КТЦ), зокрема надання телефонних консультацій із застосуванням «закону доброго самаритянина», підтвердження актуальності створення в Україні системи екстреного токсикологічного консультування. Об'єкт дослідження - КТЦ. Предмет дослідження - технологія телефонного консультування у разі гострих отруєнь хімічної етіології.

\section{Об"єкт і методи дослідження}

Матеріали Всесвітньої організації охорони здоров'я, публікації з питань діяльності КТЦ.

\section{Результати та їх обговорення}

За даними Всесвітньої організації охорони здоров'я, станом на 01.01.2020 р. у рамках Міжнародної програми хімічної безпеки активно функціонують, формуючи єдину по всьому світу інформаційну систему, близько 313 КТЦ (World Health Organization, 2020).

В Україні відсутні токсикологічні центри, однакдоступність до населення консультативної допомоги реалізується через систему екстреної медичної допомоги. Звернення за медичною допомогою у разі хімічного інциденту приймають працівники оперативно-диспетчерської служби центрів екстреної медичної допомоги та медицини катастроф. Так, в середньому за добу спеціалісти Центру екстреної медичної допомоги та медицини катастроф Київської міської державної адміністрації реєструють 60-120 запитів, пов'язаних із впливом хімічних речовин. Серед абонентів, що звертаються за допомогою, близько 75\% потребують заходів екстреної медичної допомоги, що зазвичай здійснюється бригадами на дому в потерпілого. Решта абонентів потребують екстреної госпіталізації до спеціалізованого токсикологічного центру (Київської міської клінічної лікарні швидкої медичної допомоги) або до найближчих відділень інтенсивної терапії районних лікарень міста Києва. За рік до спеціалізованого токсикологічного центру Києва госпіталізується близько 2500 дорослих осіб із тяжкими отруєннями, що потребують застосування антидотів та методів штучної детоксикації організму.

Розмови з абонентами здійснюють оператори - спеціалістилікарі медицини невідкладних станів. У складі працівників Центру $€$ спеціалісти, які проходили додаткову підготовку з діагностики та лікування гострих отруєнь на спеціальних циклах тематичного 
удосконалення кафедри медицини невідкладних станів Національної медичної академії післядипломної освіти імені П.Л. Шупика, що $€$ опорною в цьому напрямі підготовки в Україні.

Сьогодні науково-дослідні токсикологічні центри активно використовують інтернет-ресурси, пропонуючи для широкого загалу користувачів спеціалізовані інформаційні сайти, наукові видавництва, інтернет-платформи для дистанційного навчання та консультування з широкого спектра питань (International Chemical Safety Program (IPCS INCHEM), 2020; European Association of Poisons Centres and Clinical Toxicologists (EAPCCT), 2020; System of bibliographic and factual toxicological and medical computer databases, 2020; American Association of Poison Control Centers (AAPCC), 2020).

Головне завдання КТЦ - забезпечити цілодобовий доступ абонентів до різних інформаційних ресурсів таперсональної консультативної допомоги у разі гострого отруєння хімічної етіології. Однак нерідко дистанційні комунікації безпосередньо пов'язані з настанням цивільно-правової відповідальності особи, що повідомляє про інцидент або надає медичну допомогу потерпілому безпосередньо на місці інциденту.

У 2018 р. Міністерство охорони здоров'я України оприлюднило для громадського обговорення законопроєкт, який пропонує внесення до законодавства у сфері охорони здоров'я України новий термін - «імунітет від відповідальності». Документ інформує, що в ситуації, коли потерпілому в критичному стані надає першу допомогу особа, яка не має медичної освіти, ця особа позбавляється від відповідальності за свої дії. Від відповідальності пропонується звільнити особу, що надає першу допомогу навіть у разі, якщо ії дії призвели до погіршення стану потерпілого, але відповідальність залишається, якщо травми або каліцтва нанесені навмисно.

Сьогодні пацієнт, що потребує екстреної медичної допомоги, отримує ї̈ зазвичай тільки після приїзду бригади лікарів. Згідно з українським законодавством, людина, яка намагалася надати першу допомогу, але потім постраждалий помер чи отримав проблеми внаслідок цієї допомоги, може бутипритягнута до відповідальності згідно зі статтею 119 Кримінального кодексу «Вбивство з необережності». У результаті такого стану речей людина, що не впевнена у собі, воліє не надавати будь-якої допомоги. 3 іншого боку, якщо людина не надає першу допомогу у випадку, що загрожує життю іншої людини, вонаможебути притягнутадо відповідальностіза статтею 135 Кримінального кодексу — «Залишення в небезпеці».

3 метою упорядкування законодавства у складній сфері захисту і порятунку життя людини США, а потім ще ряд країн, запровадили законодавчі норми, що отримали назву «закону доброго самаритянина», який сьогодні застосовують у США та інших країнах у роботі консультативних і екстрених служб, зокрема служби «911». Положення «закону доброго самаритянина» тісно пов'язані з процесом телефонних консультацій, що здійснюються різними службами порятунку в багатьох країнах світу. Дзвінки, що здійснюються громадянами на адресу екстрених служб, нерідко передбачають повідомлення про злочин, найчастіше це - випадки вживання наркотиків, хімічно небезпечних або заборонених речовин, внаслідок чого людина потрапляє у небезпечний для свого життя стан (Drug Policy Alliance (DPA), 2020)

Наприклад, коефіцієнти смертності від передозування наркотичними і сильнодіючими речовинами в усьому світі більше ніж удвічі підвищились у період 1999-2013 рр. Лише в 2013 р. у США, за даними Центрів контролю та профілактики захворювань (Centers for Disease Control and Prevention - CDC), від передозування наркотиками померли 43982 людини, що становило близько 120 смертей на добу. Передозування призвело до більшої кількості смертей, ніж ВІЛ-інфекція/СНІД, вбивства чи автомобільні аварії. Зараз кількість випадків передозування наркотиками перевершила частоту аварій за участю транспортних засобів і вийшла на 1-ше місце середпричин смерті, пов'язаних із травмами в США.

Зазначимо, що у національному масштабі більше смертей від передозування спричинено препаратами, що відпускаються за рецептом, ніж усі разом заборонені наркотики. Наприклад, офіційні опіоїди, що відпускаються за рецептом, спричиняють підвищення смертності від передозування, зумовивши 16 тис. смертей у 2013 р. (Faul M. et al., 2016; Adusumalli J. et al., 2018).

Останнє десятиліття характеризується тим, що кількість передозувань синтетичними опіоїдами поступово перевищила кількість смертей від передозування героїном та кокаїном. Більше того, оскільки окремі держави намагалися обмежити доступ до опіоїдів, деякі люди, залежні від опіоїдів, перейшли від вживання анальгезивних препаратів за рецептом до героїну.

Трагедія в тому, що багатьох із цих смертей можна було запобігти. Шанс пережити передозування залежить від того, наскільки швидко людина отримає медичну допомогу. Результати багатоцентрових досліджень демонструють, що більшість випадків смерті насправді настає через 1-3 год після того, як потерпілий вжив або ввів внутрішньовенно наркотики. Час, який минув до того, як передозування стане смертельним випадком, є важливим для порятунку життя проміжком часу, щоб звернутися за медичною допомогою.

Найпоширеніша причина, на яку вказують респонденти, що не дзвонять вчасно за номером «911», - страх залучення поліції до розслідування інциденту отруєння. Люди, які вживають наркотики незаконно, часто бояться арешту, навіть увипадках, коли їм, їхдрузям або членам сім'ї потрібна професійна медична допомога. Крім того, суворі покарання за зберігання та незаконне вживання наркотиків, включаючи державні закони, які встановлюють кримінальні звинувачення щодо осіб, які надають наркотики тому, хто згодом помер від передозування, лише посилюють страх, який заважає багатьом свідкам звернутися за невідкладною медичною допомогою.

Ризик кримінального переслідування або цивільного судового розгляду може стримувати медичних працівників, споживачів наркотиків та сторонніх людей від допомоги жертвам передозування. Однак добре продумане законодавство може забезпечити простий захист, щоб нівелювати ці побоювання, покращити реагування компетентних служб та врятувати життя.

Важливим рішенням для заохочення свідків смертельного передозування звернутися за медичною допомогою є звільнення іх від арешту та кримінального переслідування шляхом прийняття законів про «імунітет 911» або «закону доброго самаритянина». Законодавчі акти про правовий імунітет забезпечують захист від арешту та переслідування для свідків, які викликають «911». Таке законодавство не захищає людей від арештуза інші правопорушення, такі якпродаж або торгівля наркотиками. Ця політика захищає лише особу, що повідомила про жертву передозування, від арешту та притягнення до кримінальної відповідальності за зберігання наркотиків, володіння атрибутикою та/чи перебування під впливом. Політика визначає пріоритетність порятунку життя перед арештами за володіння наркотиками.

Закони, які заохочують свідків та жертв передозування звертатися за медичною допомогою, також можуть супроводжуватися навчанням працівників правоохоронних органів та іншого персоналу з надзвичайних ситуацій та громадської безпеки. Як приклад наведемо окремі законодавчі акти. У 2007 р. Нью-Мексико став першим штатом у США, який прийняв до системи «911» принципи «закону доброго самаритянина». 3 того часу ще 27 штатів, а також округ Колумбія прийняли цей закон. Початкові результати оцінювання дії "закону доброго самаритянина" штату Вашингтон, прийнятого у 2010 р., показали, що працівники поліції та фельдшери значною мірою не знають його. Це свідчить про необхідність постійного навчання, освіти та співпраці з правоохоронними органами та іншим персоналом громадської безпеки. Однак 88\% людей, які вживають опіоїди, сказали, що з більшою імовірністю будуть повідомляти про подію та менше боятися телефонувати «911» у разі передозування, дізнавшись про такий закон.

У 2008 р. конференція мерів США одноголосно прийняла резолюцію, в якій закликала національну службу «911» до політики «закону доброго самаритянина", яка могла би врятувати тисячі життів шляхом заохочення екстреного анонімного повідомлення про передозування наркотиками, до того як настане смерть потерпілого. Аналогічна політика впроваджена у мережі кампусів і коледжів. Сьогодні в США, відповідно до «закону доброго самаритянина», у службі «911» діє >90 американських коледжів. Доведено, що така політика заохочує учнів звертатися за допомогою у разі передозування алкоголем чи/або наркотиком.

Інший аспект «закону доброго самаритянина» - пом'якшення правової відповідальностіза нанесення шкоди здоров'ю при наданні медичної допомоги поза межами медичного закладу як волонтерами, так і іншими особами.

У сучасному світі, що характеризується швидким розвитком науки й прискоренням глобалізації, люди все ще змушені звертатися за медичною допомогою. Рівень медицини постійно підвищуєть- 
ся, однак не завжди медичні заклади діють без шкоди. Трапляється, що пацієнтові не надається належна допомога чи наноситься шкода здоров'ю. У цій ситуації важливим є повне і всебічне регулювання цивільно-правової відповідальності медичних організацій та осіб, що надають медичні послуги.

Водночас у багатьох випадках медичні організації надають безоплатну допомогу і консультації пацієнтам, при цьому несучи ризик відповідальності за заподіяння шкоди. У цьому разі медична організація буде нести відповідальність за завдану шкоду, незважаючи на свої добрі наміри. Підстави для звільнення від відповідальності осіб, які здійснюють медичну діяльність, також регулюються «законом доброго самаритянина».

Щоб уникнути вищезазначених проблем у майбутньому, Міністерство охорони здоров'я України пропонує два варіанти їх вирішення:

1. Широке запровадження в Україні програми з навчання навичкам надання першої допомоги осіб, які, відповідно до своїх службових повноважень, мають ї̈ надавати. До цієї категорії належать поліцейські і працівники Національної гвардії України, рятувальники, пожежники, провідники в поїздах, бортпровідники в літаках та ін.

2. Ініціація процесу розроблення, громадського обговорення та прийняття в Україні закону, подібного до чинного в інших країнах «закону доброго самаритянина».

\section{Висновки}

У багатьох країнах світу існує «закон доброго самаритянина», що звільняє від відповідальності осіб, які надають допомогу на безоплатній основі або повідомляють про загрозу життю і здоров'ю, навіть якщо це злочин (наприклад вживання наркотиків та використання інших заборонених речовин). При цьому в багатьох країнах існують окремі норми, що звільняють від цивільно-правової відповідальності медичні установи і осіб, які здійснюють таку медичну та/або волонтерську допомогу. В українському законодавстві внаслідок відсутності зазначених норм медичні заклади часто відмовляються від надання консультативних (на відстані) та подібних медичних послуг, очікуючи цивільно-правової відповідальності.

Вирішення питання юридичного закріплення принципів надання допомоги за «законом доброго самаритянина» дозволить зберегти щороку сотні життів від передчасної смерті, тому імплементація зазначених положень у законодавство України у сфері охорони здоров'я є актуальним і своєчасним питанням для Міністерства охорони здоров'я України і професійних медичних асоціацій

\section{Список використаної літератури}

Проданчук М.Г., Калашніков А.А., Курділь Н.В. (2019) Організація підготовки фахівців у сфері профілактичної медицини в Україні: минуле і сьогодення Клінічна та профілактична медицина, 4(9-10): 12-21. DOI:10.31612/26164868.3(9).2019.02.

Трахтенберг И.М. (2010) Приоритетные аспекты профилактической токсикологии: опит прошлого, реали настоящего, горизонты будущего. Актуальні проблеми транспортної медицини: навколишнє середовище, професійне здоров'я, патологія, 3: 72-84.

Шейман Б.С., Проданчук Н.Г., Борщов С.П., Волошина Н.А. (2014) Стратегические вопросы организации системы экстренной токсикологической помощи в Украине. Медицина неотложных состояний, 2: 140-145 (http://nbuv.gov. ua/UJRN/Medns 20142 27).

Adusumalli J., Benkhadra Kh. , Murad M.H. (2018) Good Samaritan Laws and Graduate Medical Education: A Tristate Survey. Mayo Clin. Proc. Innov. Qual. Outcomes, 2(4): 336-341. doi:10.1016/j.mayocpiqo.2018.07.002.

American Association of Poison Control Centers (AAPCC) (2020) http:// www.aapcc.org/DNN.

Drug Policy Alliance (DPA) (2020) Good Samaritan Fatal Overdose Prevention Laws (https://www.drugpolicy.org/issues/good-samaritan-fatal-overdose-prevention-laws)

European Association of Poisons Centres and Clinical Toxicologists (EAPCCT) (2020) (http://www.eapcct.org).

Faul M. , Aikman S.N., Sasser S.M. (2016) Bystander intervention prior to the arrival of emergency medical services: comparing assistance across types of medica emergencies. Prehosp. Emerg. Care, 20(3): 317-323. doi: 10.3109/10903127.2015.1088605.

International Chemical Safety Program (IPCS INCHEM) (2020) (http://www. inchem.org/contents.html).

System of bibliographic and factual toxicological and medical computer databases (2020) TOXNET Resource (http://toxnet.nlm.nih.gov).

World Health Organization (2020) World Directory of Toxicology Centers (http: //www.who.int/ipcs/poisons/centre/directory/en).

\section{Гражданско-правовые аспекты \\ дистанционного консультирования \\ в случае опасного химического инцидента: "закон доброго самаритянина» \\ Н.В. Курдиль, Б.С. Шейман, О.В. Иващенко, А.В. Рогов, Т.Ю. Сафир}

Резюме. В Украине при отсутствии специализированных токсикологических центров консультативная помощь в случае химического инцидента предоставляется специалистами оперативно-диспетчерской службы центров экстренной медицинской помощи и медицины катастроф. Ceгодня вотдельныхстранахоперативно-диспетчерская служба использует положения «законадоброго самаритянина». Цель исследования-анализ опыта отдельныхстран в вопросахрегистрации телефонного сообщения об опасном химическом инциденте на основе «закона доброго самаритянина». Методы исследования: контент-анализ, сравнительный анализ. Результаты. В начале 2020 г. сеть консультативных токсикологических центров в мире была представлена 313 учреждениями в >150 странах. За последние 20 лет в работе центров увеличился спрос в телефонных консультациях, интернет-ресурсах, в частности социальных сетях, содержащих информацию о потенциальных ядах (наркотиках, алкоголе, лекарствах, пестицидах, агрохимикатах, товарах бытовой химии и т.п.). Важным аспектом в коммуникациях между оператором и абонентом является гражданско-правовая ответственность за сообщение об инциденте, который связан с действием опасных химических веществ (наркотических, токсических, взрывоопасных и др.), которая предусмотрена «законом доброго самаритянина». В статье продемонстрированы данные оположительныхрезультатахимплементациизаконав работуэкстренных служб США и других стран. Выводы. Юридическое закрепление «закона доброго самаритянина» в сфере консультативной медицинской помощи позволяетвомногихстранахмира ежегодно сохранить отпреждевременной смерти сотни жизней, поэтому имплементация этих положений в законодательство Украины в сфере здравоохранения является актуальным вопросом для профильного министерства и профессиональных медицинских ассоциаций.

Ключевые слова: острые отравления, экстренная медицинская помощь, «закон доброго самаритянина».

\section{Civil legal aspects of remote consulting in the event of a hazardous chemical incident: the good Samaritan law}

\section{N.V. Kurdil, B.S. Sheiman, O.V. Ivashchenko, A.V. Rogov, T.Yu. Safir}

Summary. In Ukraine, in the absence of specialized toxicological centers, advisory assistance in case s of chemical incidents is provided by specialists of the operational and dispatching service of emergency and disaster medicine centers. Today, in some countries around the world, the dispatch service uses the provisions of the good Samaritan law. The purpose of the study - analysis of the experience of individual countries in the field of telephone communication about a dangerous chemical incident on the basis of the good Samaritan law. Research methods: content-analysis, comparative analysis. The results. At the beginning of 2020, the network of toxicological advisory centers in the world was represented by 313 institutions in $>150$ countries. Over the last 20 years, the centers have been increasing the demand for telephone consultations, internetresources, in particular in social networks that contain information about potential poisons (drugs, alcohol, drugs, pesticides and agrochemicals, household chemicals, etc.). An important aspect in the communication between operator and subscriber is the civil liability for reporting an incident involving hazardous chemicals (narcotic, toxic, explosive, etc.), which is provided by the good Samaritan law. The article demonstrate data on the positive results of the implementation of the law to the emergency services of the USA and other countries. Conclusions. Legal consolidation of the principles of providing consultative medical care under the good Samaritan law allows saving many lives from premature death in many countries around the world, so the implementation of these provisions in Ukrainian legislation in the field of health care is a topical issue for relevant ministries and medical professional associations.

Key words: acute poisoning, emergency medicine, good Samaritan law.

\section{Адреса для листування:}

Курділь Наталія Віталіївна

03127, Київ, вул. Героїв оборони, 6

ДП «Науковий центр превентивної токсикології, харчової та хімічної безпеки імені академіка Л.І. Медведя Міністерства охорони здоров'я України» E-mail: kurdil nv@ukr.net

Одержано 09.10.2020 